\section{Involving the public in health research in Latin America: making the case for mental health}

\author{
M. Isabela Troya, ${ }^{1}$ Bernadette Bartlam, ${ }^{1}$ \\ and Carolyn A. Chew-Graham ${ }^{1}$
}

Suggested citation Troya MI, Bartlam B, Chew-Graham CA. Involving the public in health research in Latin America: making the case for mental health. Rev Panam Salud Publica. 2018;42:e45. https://doi.org/10.26633/RPSP.2018.45

\section{SUMMARY}

Patient and Public Involvement and Engagement (PPIE) has been increasingly encouraged in health services and research over the last two decades. Particularly strong evidence has been presented with regard to the impact that PPIE has in certain research areas, such as mental health. Involving the public in mental health research has the potential to improve the quality of research and reduce the power imbalance between researchers and participants. However, limitations can be frequent and include tokenistic involvement and lack of infrastructure and support. Nevertheless, PPIE has the potential to impact mental health research in the Latin American context, where existing policies already support public involvement in health research and where the burden of mental disorders is significant. There are many lessons to learn from the evidence of PPIE in other regions. Latin America now has the opportunity to tackle one of today's most important issues: effective health care service delivery for all, based on evidence from comprehensive health research.

Keywords: Health research policy; community-based participatory research; mental health; Latin America.

\footnotetext{
Research Institute for Primary Care and Health Sciences, Keele University, Newcastle-under-Lyme, Staffordshire, United Kingdom. Send correspondence to M. Isabela Troya, m.i.troya. bermeo@keele.ac.uk
}

The concept of Patient and Public Involvement and Engagement (PPIE) in health research and health services delivery has been present and influential for nearly four decades, since the World Health Organization published the "Declaration of AlmaAta" (1). The declaration states explicitly that citizens have both a duty and a right to participate in health care implementation and planning (1). PPIE has progressed since then, with governments worldwide developing health policies and amending legislation to involve the public in health research and service provision $(2-6)$. However, because a power shift like this requires more than governmental support, some governments have not successfully engaged the public despite policy and legislative changes.

For the purpose of this paper, PPIE will refer to the need for involving the public in health research. The case will be made for increased PPIE in health research, particularly mental health research, in Latin America where the rise in noncommunicable diseases related to mental health has made an immense contribution to the burden of disease.

\section{What is Patient and Public Involvement and Engagement and why is it important?}

In recent decades, technology, medicine, and health services have advanced significantly. These advances, which were in part due to health research, have helped reduce mortality and increase life expectancy (7).

The emergence of PPIE came after a social movement and public demands to be included in decisions regarding health services for all. Given that the public is composed of health consumers, public input can help mitigate the complex task of meeting a population's multiple and diverse health needs. It should be noted that in PPIE, the "public" is not limited to patients; rather, it includes caregivers, potential patients, and any organization that represents people who use health services (3). Much literature has explored the impact of PPIE on health services $(8,9)$. Now, there is growing evidence of the impact that PPIE can have on health research as well (10).

The available literature on this topic often uses terms similar to PPIE, such as Community Participatory Research (CPR). However, PPIE is unique as it advocates for consulting the public throughout the entire research process, from design to delivery, and includes funding, planning, conducting, and disseminating research (11). But it is important to note that, unlike CPR, PPIE is solely focused on consultancy and advice, not

This is an open access article distributed under the terms of the Creative Commons Attribution-NonCommercial-NoDerivs 3.0 IGO License, which permits use, distribution, and reproduction in any medium, provided the original work is properly cited. No modifications or commercial use of this article are permitted. In any reproduction of this article there should not be any suggestion that PAHO or this article endorse any specific organization or products. The use of the PAHO logo is not permitted. This notice should be preserved along with the article's original URL. 
on direct participation in terms of participants or researchers.

Public involvement is important because it enriches health research by gaining insight and experiences from the public, while aiming to be equitable, transparent, and of the highest possible quality. PPIE also gives researchers the opportunity to build a connection with the public and to transform research findings in a way that is transferable and understood by the general public.

\section{Public involvement in health research}

PPIE can be included at different stages of health research, as suggested by the United Kingdom's National Institute for Health Research advisory group, INVOLVE-from inception or development of a research idea to later stages, such as disseminating findings (12). The unique value and contribution that PPIE brings to these stages are: increased research relevance, greater understanding of a patient's acceptance of treatments, an improved informed consent process, a better experience by research participants, and enhanced dissemination of findings (3). Some of the highlights of PPIE have been higher quality health research and an increased understanding of the public's needs $(13,14)$. PPIE has also had an impact on government health care priority-setting, demonstrating its significant influence (15). Particularly in the case of mental health, PPIE has played a fundamental role (16).

Evidence for PPIE is strong in health research $(10,17$, 18). Despite its monetary and resource costs, PPIE is particularly beneficial to patients and the public when it is earnest, not tokenistic (9). Engaging the public in health research, at any stage, does have associated costs and inevitable expenses; however, these costs are justified by increased study success and effectiveness (16). PPIE can also enhance research by improving study feasibility and recruitment of participants (16). Also, NIHR summarizes the benefits of PPIE for health research as follows (19):

- Identifying and addressing any possible ethical concerns

- Determining best contact hours or times for participants

- Identifying ways to facilitate participation (e.g., travel arrangements for participants)

- Determining priorities in research conducted

- Establishing appropriate length of questionnaires

Giving the public an opportunity to influence health research shifts responsibility, from a classic health care model in which patients are merely spectators of their health to a collaborative and proactive model (20). This is important as it helps mitigate frequent power imbalances between researchers and health services clients.

In addition to the evidence for PPIE in health research, an ethical argument must be considered. Health research attempts to expand knowledge on the management of health conditions and is exclusively conducted and aimed to benefit people. Attempting to create knowledge of an inherently human condition, such as health, without consultation of its users, has a fundamental flaw of validity and applicability (20).

By changing from the classic model to a proactive one that involves the public in co-creating research knowledge, studies are enriched by its users and become more approachable, effective, and pragmatic. There is risk, however, of falling into tokenistic involvement, and therefore, misinterpreting the public's input into research.

\section{Public involvement in mental health research}

Mental health is an area with strong evidence for PPIE in research $(16,17)$. Evidence suggests that involving the public in mental health research enhances the quality of research $(21-23)$. Research also suggests that PPIE not only benefits health services users, but also has an effect on the researchers carrying it out. Two systematic reviews found that researchers using PPIE in their work were positively influenced by challenging their attitudes and beliefs towards mental health, as well as enjoying the partnership with the public and becoming more empathetic towards service users $(22,24,25)$. This is particularly important in mental health, which has been historically associated with stigma and discrimination (26), even on the part of researchers and mental health professionals (27). Findings from research that involved the public also showed a negative side: researchers reported significant financial resources and time spent on PPIE (22, 25). Financial constraints may jeopardize research quality and are a common barrier encountered by researchers (22).

But why address PPIE in mental health research in Latin America? For decades, researchers and policymakers worldwide have noted the importance of addressing mental health conditions; lack of treatment is unacceptable due to its high burden on society (28). In the latest WHO report on Latin America (29), findings showed that nearly one-quarter of the burden of disease is caused by mental health disorders.

Following worldwide patterns, Latin America is greatly hindered by increasing rates in mental health conditions, a situation worsened by the numbers left untreated. Combined with the lack of accessibility due to largely centralized mental health systems, an important burden of disease has ensued (29). PPIE in mental health research can help reduce the burden, producing more effective research and development in health services delivery.

There is also an ethical argument for involving the public in mental health research. Mental health is the only area in which patients can be treated without consent (30). This raises multiple ethical concerns that are not the focus of this paper, but which underscore the unusual space that mental health occupies on the health research spectrum. This also highlights the 
capacity that service users may have for being involved in mental health research. Acknowledging these concerns, the Health Research Authority (London, United Kingdom), a government body charged with ethical approvals for health and social care research, developed a strategy that emphasizes PPIE in all health research (including mental health) for good ethical practice (19).

\section{Challenges for public involvement in health research}

Possible pitfalls for PPIE in health research have been identified by previous studies $(8,22,25)$. Common limitations include: sustainability issues, time constraints, competing objectives and priorities from research teams, the need for additional monetary resources, and organizational leadership. Solutions to these issues have yet to be addressed comprehensively, however they seem to be a matter of organizing and managing time and resources in order to reap the benefits of public involvement.

Perhaps one of the biggest concerns is the risk of falling into tokenistic involvement in health research $(31,32)$. Being an important requisite for applying for funding in health research in many countries, PPIE risks tokenistic involvement from researchers under multiple time and resource constraints. As Green (31) highlights, contemporary health research does provide evidence of the presence of PPIE; however, the role the public plays lacks weight, and more equitable contributions and partnerships are needed between the public and researchers (31). Also, as Madden and Speed (33) argue, there is no guarantee that public participation in health research will definitely improve health outcomes. However, when done earnestly, PPIE can improve relationship dynamics and further an understanding of the public's health priorities.

Another barrier to meaningfully involving the public in research is the public's low levels of health literacy and understanding of health policy (34). These may lead to power imbalances between researchers and the public, which may deter meaningful dialogue and limit involvement. This is something researchers should be prepared to address in order to avoid superficial involvement.

Jinks and collaborators (35) provide evidence for dealing with some of the aforementioned issues, i.e., sustainability, time, and resource constraints. Organizational commitment, as well as leadership, adequate resourcing, and support infrastructure were identified as key elements for PPIE sustainability in a primary care research center (35) and could be translated to broader health systems, both at the national and regional levels.

PPIE will inevitably vary depending on the context in which it is embedded; however, by identifying possible barriers and creating manageable solutions to potential pitfalls, they can be resolved. Also, by previ- ously identifying the risk of tokenistic involvement, researchers can approach PPIE in a different manner, accessing the training tools available $(36,37)$, receiving the required support, and conceptualizing PPIE involvement in research as a collaborative, co-construction of health knowledge.

\section{Lessons for Latin America}

During the last decade in Latin America, government efforts have been made to involve the public in health research; specifically, Chile, Colombia, and Ecuador have put policies, guidelines, and/or legislation in place for PPIE $(4,38,39)$. Nevertheless, PPIE in Latin America is under-developed. Although policies exist in some countries, the reality is that there is still significant work to be done. This lag may be due to various historical, political, and socioeconomic circumstances, such as political instability and lack of monetary resources.

However challenging it might be, involving the public in research is also an opportunity to tackle one of today's most important issues: effective health care service delivery for all, one of the United Nation's Sustainable Development Goals for 2030 (40). This can be done by adequately conceptualized and conducted PPIE in health research that identifies the public's priorities.

Other countries around the world have had PPIE present for longer periods. This gives Latin America the opportunity to learn from what has been proven to work and to avoid what has been ineffective. Numerous studies have addressed a range of questions regarding PPIE effectiveness and summarized current evidence $(8,17,31,32)$. By critically appraising PPIE evidence in other nations, Latin America can adapt it to each country's context, taking the steps necessary to avoid common failings (Figure 1). Latin America now has the opportunity to show how PPIE can further benefit health research in the region, while creating more effective and cost-effective interventions that are more accessible to users.

\section{Conclusions}

Noncommunicable diseases are the leading cause of the global disease burden, with mental health disorders contributing nearly one-fourth of the total in Latin America. Current health care services in place for mental health disorders are not enough, leaving many without access and treatment. This gap could be addressed by mental health research that identifies effective and approachable treatment strategies.

Following the compelling evidence shown for PPIE in other areas, Latin America would benefit greatly from PPIE to produce more effective and higher quality health research, especially in mental health. Latin America also has the opportunity to be a pioneer in some aspects of PPIE, addressing some of the caveats such as tokenistic involvement and strengthening the 
FIGURE 1. Common pitfalls of including Patient and Public Involvement and Engagement (PPIE) in health research

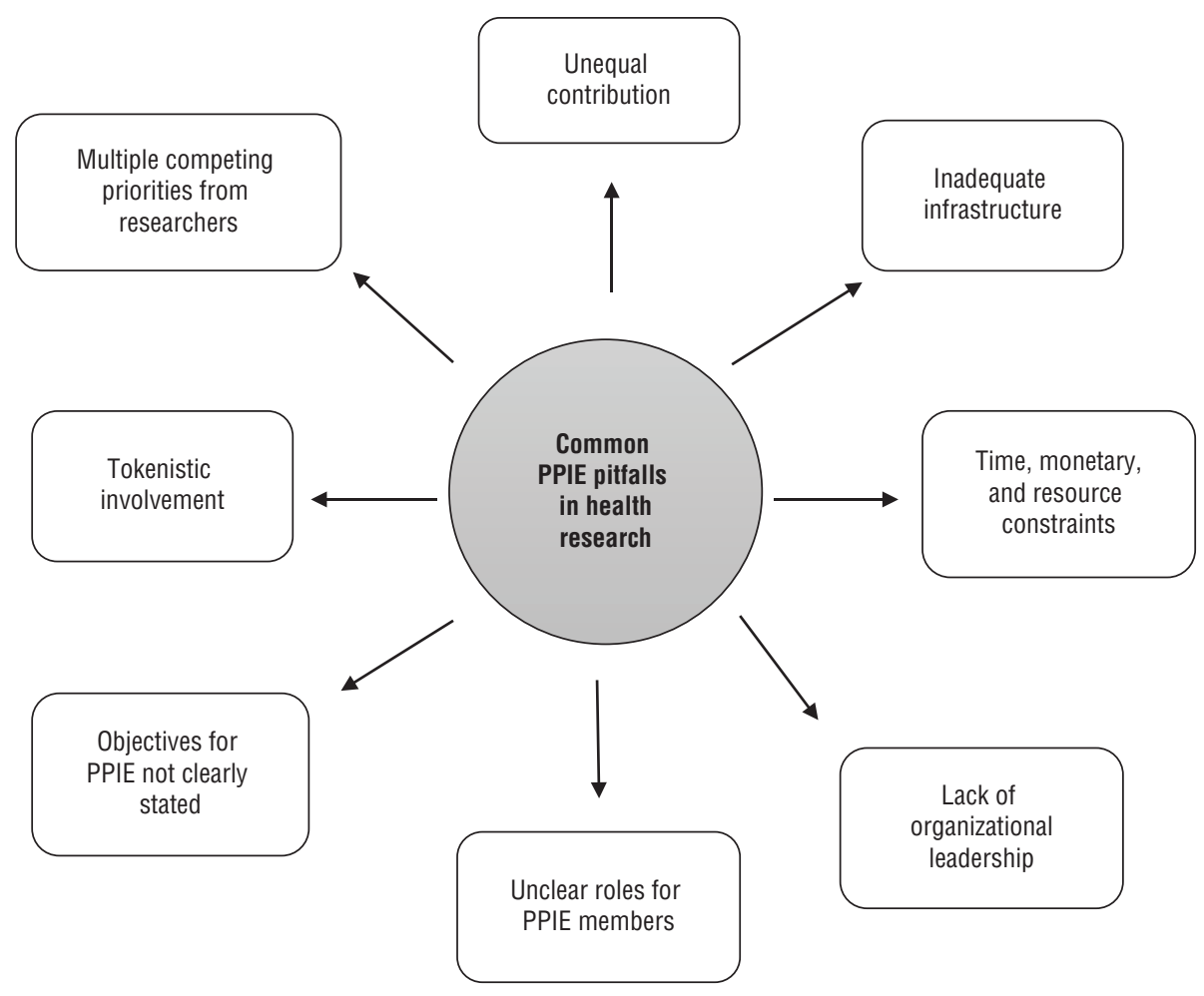

Source: Prepared by the authors from the study data.

scant theoretical development and conceptualization in the field.

The stage has been partially set by existing policies in many countries declaring the need for PPIE in health research. Latin America now has the opportunity to address the issue of providing effective health care and treatment through comprehensive health research. It is the time for researchers, policymakers, and funders to take the opportunity to benefit from co-creation of knowledge and the higher quality of research produced when patients and the public are involved and engaged in health research, particularly mental health research.

Acknowledgements. The authors wish to thank the PPIE Team at the Research Institute for Primary Care and Health Sciences, Keele University (Newcastleunder-Lyme, Staffordshire, United Kingdom).
Funding. IT was funded by a Keele University ACORN studentship. Additional funding has been granted to IT by Santander Bank. CC-G was partly funded by NIHR West Midlands Collaboration for Leadership in Applied Health Research and Care, and South Staffordshire and Shropshire Healthcare National Health Service Foundation Trust. None of the funding bodies had any role in the design, analysis, or interpretation of this manuscript.

Conflicts of interest. None declared.

Disclaimer. Authors hold sole responsibility for the views expressed in the manuscript, which may not necessarily reflect the opinion or policy of the RPSP/ PAJPH and/or PAHO.

\section{REFERENCES}

1. World Health Organization. Declaration of Alma-Ata. Proceedings of the International Conference on Primary Health Care, Alma-Ata, USSR, 6 - 12 September 1978. Alma-Ata: WHO; 1978.

2. Canadian Institute of Health Research. Guidelines for health research involving aboriginal people. Ottawa: Canadian Institute of Health Research; 2007.
3. INVOLVE. Going the extra mile: improving the nation's health and wellbeing through public involvement in research. London: INVOLVE; 2014.

4. Ministerio de Salud, Gobierno de Chile. Participación ciudadana en atención primaria: un aporte al desarrollo del Modelo de Atención Integral de Salud familiar y comunitario y la satisfacción usuaria. Available from: http://web.minsal. cl/wpcontent/uploads / 2016/09/2_PARTICIPACI\%C3\% 93N-CIUDADANA-APS.pdf Accessed 23 January 2017.

5. National Health and Medical Research Council. Statement on Consumer and Community Participation in Health and Medical Research. Canberra: National Health and Medical Research Council; 2001.

6. World Health Organization. The Tallinn Charter: Health Systems for 
Health and Wealth. Copenhagen: WHO; 2009.

7. World Health Organization. World Report on Ageing and Health. Geneva: WHO; 2015.

8. Mockford C, Staniszewska S, Griffiths F, Herron-Marx S. The impact of patient and public involvement on UK NHS health care: a systematic review. Int J Qual Health Care. 2012;24(1):28-38.

9. Oliver SR, Rees RW, Clarke-Jones L, Milne R, Oakley AR, Gabbay J, et al. A multidimensional conceptual framework for analyzing public involvement in health services research. Health Expect. 2008;11(1):72-84

10. Thompson J, Bissell P, Cooper C, Armitage C, Barber R. Credibility and the 'professionalized' lay expert: Reflections on the dilemmas and opportunities of public involvement in health research. Health (London). 2012;16(6):602-18.

11. Thompson J, Barber R, Ward PR, Boote JD, Cooper CL, Armitage CJ, et al. Health researchers' attitudes towards public involvement in health research. Health Expect. 2009;12(2):209-20.

12. National Institute for Health Research of the United Kingdom. The research cycle. Available from: www.nihr.ac.uk/patients-andpublic/how-to-join-in/the-research-cycle/ Accessed 25 March 2017

13. Smith E, Ross F, Donovan S, Manthorpe J, Brearley S, Sitzia J, et al. Service user involvement in nursing, midwifery and health visiting research: a review of evidence and practice. Int $\mathrm{J}$ Nurs Stud. 2008;45(2);298-315.

14. Crawford MJ, Rutter D, Manley C, Weaver T, Bhui K, Fulop N, et al. Systematic review of involving patients in the planning and development of health care. BMJ. 2002; 325(7375);1263.

15. Mitton C, Smith N, Peacock S, Evoy B, Abelson J. Public participation in health care priority setting: a scoping review. Health Policy. 2009;91(3):219-28.

16. Ennis L, Wykes T. Impact of patient involvement in mental health research: longitudinal study. $\mathrm{Br} \mathrm{J}$ Psychiatry. 2013;203(5):381-6.

17. Brett I, Staniszewska S, Mockford C, Herron-Marx S, Hughes J, Tysall C, et al. A systematic review of the impact of patient and public involvement on service users, researchers and communities. Patient. 2014; 7(4):387-95.
18. Boote J, Baird W, Sutton A. Public involvement in the systematic review process in health and social care: a narrative review of case examples. Health Policy. 2011;102(2): 105-16.

19. National Institute for Health Research. Is 2017 the year for PPIE? Available from: www.nihr. ac.uk/news/is-2017-the-year-forppie/5538 Accessed 1 May 2017.

20. Seedhouse D. Ethics: the heart of health care. Chichester: John Wiley \& Sons; 2008.

21. Faulkner A. Principles and motives. Handbook of service user involvement in mental health research. Chichester: Wiley-Blackwell; 2009.

22. Staley K. Exploring impact: public involvement in NHS, public health and social care research. London: National Institute for Health Research; 2009.

23. Lowes L, Robling M. R, Bennert K, Crawley C, Hambly H, Hawthorne $\mathrm{K}$, et al. Involving lay and professional stakeholders in the development of a research intervention for the DEPICTED Study. Health Expect. 2011;14(3):250-60.

24. Hewlett S, Wit MD, Richards P, Quest E, Hughes R, Heiberg T, et al. Patients and professionals as research partners: challenges, practicalities, and benefits. Arthritis Rheum. 2006:55(4):676-80.

25. Brett J, Staniszewska S, Mockford C, Seers K, Herron-Marx S, Baylis $\mathrm{H}$. The PIRICON study: a systematic review of the conceptualization, measurement, impact and outcomes of patient and public involvement in health and social care research. London: UKCRC; 2010.

26. Thornicroft G. Stigma and discrimination limit access to mental health care. Epidemiol Psichiatr Soc. 2008;17(1):14-9.

27. Schulze B. Stigma and mental health professionals: a review of the evidence on an intricate relationship. Int Rev Psychiatry. 2007;19(2):137-55.

28. Kessler RC, Aguilar-Gaxiola S, Alonso J, Chatterji S, Lee S, Ormel J, et al. The global burden of mental disorders: an update from the WHO World Mental Health (WMH) surveys. Epidemiol Psichiatr Soc. 2009;18(1):23-33.

29. Pan American Health Organization. WHO-AIMS Report on mental health systems in Latin America and the Caribbean. Washington DC: PAHO; 2013.

30. Fennell P. Treatment without consent Law, psychiatry and the treatment of mentally disordered people since 1845. London: Routledge; 2002.

31. Green G. Power to the people: To what extent has public involvement in applied health research achieved this? Res Involv Engagem. 2016;2(1):28.

32. Domecq JP, Prutsky G, Elraiyah T, Wang Z, Nabhan M, Shippee N, et al. Patient engagement in research: a systematic review. BMC Health Serv Res. 2014;14(1):89.

33. Madden M, Speed E. Beware zombies and unicorns: toward critical patient and public involvement in health research in a neoliberal context. Front Sociology. 2017;2(7)

34. Nutbeam D, McGill B, Premkumar P. Improving health literacy in community populations: a review of progress. Health Promot Int. 2017 dax015.

35. Jinks C, Carter P, Rhodes C, Taylor R, Beech R, Dziedzic K, et al. Patient and public involvement in primary care research-an example of ensuring its sustainability. Res Involv Engagem. 2016;2(1):1.

36. INVOLVE. What is public involvement in research? Available from: www.invo.org.uk/find-out-more/ what-is-public-involvement-inresearch-2/ Accessed 24 November 2016.

37. National Institute for Health Research. Patients and the public. 2014. Available from: https:// www.nihr.ac.uk/patients-andpublic/ Accessed 8 May 2017.

38. Comisión Nacional de Seguimiento a la Propuesta de Reforma Integral de Salud. Propuesta politica de articipación social en salud. San Salvador: CNSPRIS; 2006.

39. Ministerio de Salud Pública del Ecuador. Manual del modelo de atención integral de salud. Quito: MSP; 2012.

40. United Nations Development Programme. Sustainable development goals. 2017. Available from www.undp.org/content/undp/ en/home/sustainable-developmentgoals.html Accessed 1 December 2017.

Manuscript received on 16 June 2017. Accepted for publication on 10 December 2017. 
RESUMEN

Participación del público en las investigaciones de salud en América Latina: su importancia en el ámbito de la salud mental

Palabras clave
En los últimos 20 años, se ha fomentado cada vez más la participación y el compromiso de los pacientes y el público en los servicios de salud y las investigaciones en el campo de la salud. Se ha presentado evidencia particularmente contundente con respecto a la repercusión de esta participación y compromiso en ciertas áreas de investigación, como la salud mental. Incluir al público en las investigaciones sobre salud mental tiene el potencial de mejorar la calidad de las investigaciones y reducir el desequilibrio de poder entre los investigadores y los participantes. Sin embargo, con frecuencia hay limitaciones, entre las cuales se encuentran la participación simbólica y la falta de infraestructura y apoyo. No obstante, la participación y el compromiso de los pacientes y el público pueden tener una repercusión importante en las investigaciones sobre salud mental en América Latina, donde las políticas vigentes ya apoyan la participación del público en las investigaciones de salud y la carga de los trastornos mentales es significativa. Se puede aprender mucho de la evidencia acerca de este tipo de participación y compromiso en otras regiones. Actualmente América Latina tiene la oportunidad de abordar uno de los problemas más importantes de hoy: cómo prestar servicios eficaces de atención de salud que estén al alcance de todos y se basen en la evidencia derivada de investigaciones en el ámbito de la salud.

Política de investigación en salud; investigación participativa basada en la comunidad; salud mental; América Latina.

RESUMO O envolvimento e a participação dos pacientes e do público (EPPP) vêm sendo incentivados cada vez mais nos serviços de saúde e em pesquisas nas duas últimas décadas. Existem evidências sólidas que demonstram a repercussão do EPPP em certas áreas de pesquisa como saúde mental. Envolver o público em pesquisa de saúde mental tem o potencial de melhorar a qualidade das pesquisas e reduzir o desequilíbrio de poder entre pesquisadores e participantes. Porém, frequentemente são observadas limitações como o envolvimento simbólico e a falta de infraestrutura e de apoio. Contudo, o EPPP podem ter impacto na pesquisa em saúde mental no contexto latino-americano, onde existem políticas que apoiam o envolvimento do público em pesquisa em saúde e onde o ônus dos transtornos mentais é considerável. Muitos ensinamentos podem ser tirados das evidências obtidas com o EPPP em outras regiões. A América Latina tem agora a oportunidade de lidar com uma das questões atuais mais importantes: a prestação eficiente de serviços de saúde para todos, com base em evidências obtidas de pesquisas abrangentes de saúde.

Palavras-chave

Política de pesquisa em saúde; pesquisa participativa baseada na comunidade; saúde mental; América Latina. 